\title{
近世文書にみる「洗い」と「洗い屋」について \\ ABOUT THE “ARAI”, AND “ARAI-YA” \\ IN DOCUMENTS FROM AROUND THE EDO PERIOD
}

\author{
中 山利 恵 ${ }^{* 1}$ \\ Rie NAKAYAMA
}

\begin{abstract}
This paper analyzes the depiction of "ARAI (washing)" in work-related literary documents from around the Edo period to clarify objects such as lye used in "ARAI," the operators who performed the ARAI, and the activities involved in ARAI operations. Also, by examining these records historically, the transition of "ARAI" in construction activities mainly for repairs from the Keicho era in the early Edo period to the Tenpo era in the late Edo period is examined. We clarified the "ARAI" was carried out by professional craftsmen described as "Arai-ya" and "Arai-kata" from Genroku era in the middle Edo reriod.
\end{abstract}

Keywords : ARAI (washing), AKU-ARAI, ARAI-YA, Purification techniques of cortex, Repair 洗い, 灰汁洗い, 洗い屋, 木肌浄化処理, 建築修理

\section{1. はじめに}

本論は、近世の作事関係文書に記載された「洗い」に関する記述 を分析することで、当時の「洗い」に用いられた薬液などの用途物、 「洗い」を行った施工者や、各々の洗い仕事の内容を明らかにする ことを目的としている。さらに、これらの記録を通史的に見ていく ことで、近世初期の慶長年間から近世末期の天保年間までの修理を 主とした建設行為における「洗い」の変遷を検証していく。

「洗い」とは、灰汁や水、苛性ソーダ等の溶液で建築の露出した 木部を洗い、木材表面の污れや変色を落とす技術である。最も一般 的に知られているのが、経年した建築の污れや古色を落とす古建築 の洗いであるが、建設過程で付いた手垢や污れを取り除くため、新 築時に行われる「新築の洗い」も存在している。筆者はこれまで、 歴史史料および文献調査をはじめ、「洗い屋」と呼ばれる現役の洗い 職人への聞き取り調査や、現代に伝わる伝統的洗い道具の調查を行 (1)、その歴史的変遷と、そこから推察される建築の経年に対する 美意識について明らかにしてきた2)。

近世においては、慶長六年（1601）大徳寺の『真珠庵本坊東方江 次出作事小日記』に、客殿の洗いを行う為に葍を三升一合仕入れた 記録が残されていることを指摘した。また『南禅寺総門・脇門・北 門普請帳并風呂修補』の作事記録には、寛永十八年（1641）御所か ら移築した日ノ門（現栜使門）の洗い手間が、左官の請け取りとし て計上され、蕎麦葍と推測される「蕎麦木」と色付け用の油が計上 されていたことを示した。そして承応元年（1652）には、『南禅寺 祠堂・新門・経蔵・倉司作事下行帳』における祠堂の間の造営にお
いて、左官の洗い手間と洗い用の「蕎麦葈拾六束」が、壁塗りと共 に計上されていることを明らかにしだ3。

しかしながら、史料上の洗いの記録は上記 3 点の文書への言及に とどまり、さらなる史料収集が望まれる状態であった。また上記に より、寛永期には左官職人が洗いを行っていたことを明らかにでき たが、洗いの専門職である「洗い屋」が、いつから存在したのかに ついては、洗い職人への聞き取りによる考察に留まっていだ)。

そこで今回は、京都・奈良・滋賀の文化財建造物修理工事報告書 に掲載されている修復工事関係史料の記録や、社寺建築の造営記録 における洗いの記録を収集し検討した。上記地域に限定した理由は、 これまで筆者が聞き取りをした洗い職人のほとんどが関西（主に京 都・大阪）在住者であり、関東在住の職人も先代が関西で修行をし ていたという情報を得ていたためである5)。また、上記 3 府県は、 文化財指定建造物数に比例して修理工事報告書の発行部数が特に多 く ${ }^{6}$ 、作事関係史料の掲載数も総じて多い傾向があるため、調査対 象として選定した。

上記作業により、さらに 10 点の史料における洗いの記録を確認し、 新たな知見を得ることができた。

以上を踏まえ本論では、まず、これらの史料における洗いの記録 を紹介しながら時系列に示す。次いで、洗いに用いられた薬液や道 具などの用途物、洗いの種別、洗いの施工者、施工規模などの工事 内容を分析する。さらに、各々の記述から、慶長期から近世末期に かけて「洗い」の仕事が、どのように变化し発展を遂げたのか、そ の変遷を明らかにしていく。 
2. 近世文書にみる「洗い」

慶安二年 (1649) 大徳寺龍光院昭堂新築工事における「左官」の洗 いと新築の「拭手間」

慶安二年（1649）作成の『龍光院昭堂普請材木帳』（大徳寺 龍光 院 蔵)には、大徳寺龍光院に現存する昭堂の建立に当たり、材木を 始めとする諸材料や諸職方の手間などの詳細が記録されている。こ こに記された洗いの記録を以下に示す。

一五百目 左官客殿洗手間

一 三十五多 昭堂拭手間

一八十七多 白土坪数 四十三坪半 但手間共

一 五十二各 手間賃 下塗中塗共但二十六人 一人二付二必宛 ${ }^{7)}$

[傍点筆者 $]$

「左官客殿洗手間」より、1 章で示した南禅寺日ノ門・祠堂同様、 洗い手間が、左官が行うものとして計上されているのが分かる。ま た、ここで記された「客殿」は、寛永年間（1624-1643）建立の現 在の書院と考えられる。このため、新築される昭堂に合わせて、築 6〜25 年程度を経た客殿を左官職人が洗ったことが見て取れる。さ らに注目されるのは、客殿洗いに引き続き記載された「三十五多 昭 堂拭手間」の記述である。経年した既存の客殿の洗いと共に、新築 された昭堂の「拭 (ぬぐい) 手間」が計上されている。「洗い」とい う言葉が用いられていないため、布巾等を用いた水拭きまたは乾拭 きだったと考えられる。現代の伝統的洗い仕事でも行われている、 建設過程で付いた手垢や污れを取り除くための「新築の洗い」に通 じる仕上げ拭きであったと推察される。管見では、近世の作事関係 文書で新築建物に「新築の洗い」に近い行為が記録された唯一のも のである ${ }^{8)}$ 。そして「白土坪数四拾三坪半」「下塗中塗共但廿六人」 の記述から、下塗り・中塗りと、仕上げの白土が手間賃と共に計上 され、通常の壁を施工する左官仕事も行われていたことが読み取れ る。このため、昭堂の拭い手間も、洗いと同種の仕事として左官が 行っていたことが分かるのである。

\section{寛文八年（1668）延暦寺諸堂修復工事における洗いと「しらけ」と 古色繕いの併用}

寛文八年の日付のある『御修復 伏見屋見積 比颚山山上 根本 中堂 廻廊 文珠楼 大講堂 鐘撞堂』（延暦寺 蔵）は、寛永十九 年 (1642) 徳川家光の命による延暦寺諸堂再建後の最初の修理記録 である ${ }^{9)}$ この工事は、屋根莫き替えと腐朽した柱の根継と造作の 修理等を主としており、解体を伴わないが比較的規模の大きい修理 であったことが読み取れる。

根本中堂（中略）

一、総槻丸柱ため塗縁かわの柱外の方はげ申候同裏のがわ両妻 ともに柱外の方土朱塗内の方ため塗総柱敷八十四本柱根不残朽 候内五十一本八内陣外陣入側の根つぎ一丈三尺より一丈迄、(中 略）四方外䞟り之柱根つぎの分外之方土朱三心゙んぬり同内の方 ためぬりとも古きに之り合し様に塗継何も漆に念を入可申

(中略)

一、縁がは入側拭板所々損じ候間不残取はなし損じ朽し分檜割 木こなしにて板の的㷞さ古きに取合様に致し取かへ古き分は し 宁元の如くに取付可申事 (中略) 大講堂 (中略)
一、内陣迴り置床かまち短貫ともに土朱好同根太尾引板とも に所々朽候間檜寸立こふしにて朽候分取か一主朱古き海合様 忞弃文方継可申候（中略）

一、総はめ不残取はなし所々朽り候間檜寸立こふしにて朽候分 取かーはら゙厚さ以前のことくに致し仕様古き同前主朱主扁叙漆

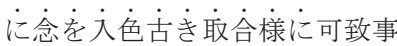

(中略)

一、諸々の堂内外ともに楽事致し所切方宂に愈主洗可申事 10)

[傍点筆者 $]$

各々の建物ごとに、細かな造作材の腐朽部分の取り換え、彩色の 繕い等が指示されている。注目されるのが、既存に仕様を合わせる 指示が多数みられる点である。根本中堂の「柱根つぎの分外之方土 朱三べんぬり同内の方ためぬりとも古きにとり合わし様に塗継」や、 大講堂における「主朱三扁塗䊫に念を入色古き取合様に可致」は、 根継や取り換えによる新規材への土朱の塗装を、古いものに合わせ て塗り継ぐという仕様であり、現代の彩色や塗装の古色補修と同様 の行為である。さらに根本中堂の「板穴は今゙厚さ古きに取合様に致 し取かへ古き分はしら官元の如くに取付」から、取り換え材は既存 に厚みを合わせ、かつ古材は「しらけ」つまり木材の表面を削り新 しい木肌を見せることで、新規材への調和を図っている ${ }^{11)}$ 。

さらに諸堂の修理仕様を記載した後に、大工木引小屋の場所や、 大工・木引・屋根莫・日用人工などが一式計上され ${ }^{12)}$ 、諸々の雑費 が記載されている。そして、その末文に「諸々の堂内外ともに楽事 致し所切わらに念念文洗」との記載がある。「楽事」は、修理の落 慶法要等で行われる法楽の意であると推察される ${ }^{13)}$ 。それらの儀礼 空間として用いられる諸堂は、内外共に「切わら」を用いて「念を 入」れて洗う指示が記されている。「切わら」は、葈を束ねた「たわ し」の意であると考えられる ${ }^{14)}$ 。現代の洗いでは木肌を洗うために 用いられる「葈䈦」の原型と考えられる。しかしながら、当時の根 本中堂・大講堂は共に「柱外の方土朱塗内の方ため塗」であり、屋 外側の柱は土朱塗、屋内の柱は漆の溜塗であった。上述したように 本工事の塗装に関しては古色繥いを主とした修復であったため、塗 装塗替えのための洗い落としの意味ではないと判断できる。洗いを かける部位の指示も無いため詳細は不明であるが、加持祈祷で護摩 木を焚くこと等により煤が付いた殿内や、屋外の埃などの污れを、 修理の仕上げとしてざっと洗い流す仕様だったのかもしれない。

また経年した建築の古色への調和を図る塗装の古色繕い、新材へ の調和を図る「しらけ」、そして塗装のある堂内外全体の洗いが併用 された興味深い事例であると言える。

\section{元禄六年（1693）福王子神社拝殿修復工事における灰汁洗い}

元禄六年に作成された『仁和寺諸堂社御修復仕様入札帳』(仁和寺 蔵）には、仁和寺諸堂社の筆頭として書かれた福王子神社拝殿の修 復仕様に洗いの記録が残されている。

元禄六年西 三冊之内
仁和寺諸堂社（中略） 御修復仕様入札帳

福王子社 表七尺二寸 奥へ一丈六寸 三方大床高欄有 (中略)

同所拝殿 桁行三間 梁間二間 四方二落縁有 （中略） 右之御修復仕様 
(中略)

一 切目長押はい十四ふ足仕足可申候内法長押釗隠にあらい馢 指直し可申候事

一 制折廻り柱長押天井落縁廻敷板両妻破風狐かうし ${ }^{15}$ )共一式 そばがらのあ之老以洗拭可申候事

一 四方縁下まんちう形（割注：長延テ十一間折廻リ二尺）欠 損申二付下地补は土を以築堅入中塗白土塗直し可申候事

一 四方内法長押上小壁白土損こそけをとし上塗白土塗直し縁 下小壁損シ下地繥仕直所荒塗上塗仕其外古白土こそけおと し上塗白土共塗直し可申候事（後略） ${ }^{16)}$

[傍点筆者 $]$

現存する福王子神社の社殿は、仁和寺の鎮守として寛永年間（17 世紀前半）に建立されている。本殿は一間社春日造で丹塗が木部全 体に施されているが、拝殿は桁行三間梁間二間の柱間が開放で塗装 の無い簡素な建物である。

本史料においても、本殿には「鴾にぬり（丹塗）柱長押桁たる木 茅負裏側落縁高欄迴縁束御拝敷板かまち土囊扉共何も損下地すりは がし塗直し可申候事」17)という塗装塗り直しの仕様が記されている。 一方扯殿は白木の建物であるため、塗装に関する仕様記載は無く、 屋根修理や建物内の隙の繥いの指示の他に、飾り金物と主要木部の 「洗い」に関する仕様が記録されている。

切目長押の唄 (ばい: 半球形の釘隠) の不足分を足し、内法長押 の釘隠は煮洗いし、箔の指し直しを行うとある。そして四周すべて

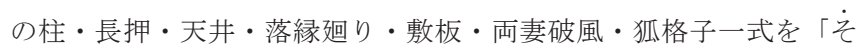

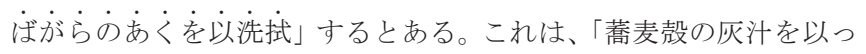
て洗い拭き」という意味と取ることができ、䒾麦殼の灰を煮出して 作った灰汁を、择殿の木部全体の洗いに用いた事例と考えることが できる。そして縁下の亀腹の欠損部分を塗り直し、長押上の小壁と 縁下の小壁は傷んだ上塗壁材をこそげ落として塗り直すとしている。

これらのことから、元禄六年 (1693) の時点で計画された福王子 神社の修復は、本殿の修復と塗装の塗り直しに合わせて、拝殿も白 木の木部全体に洗いをかけて社殿を一新する工事であったことが分 かる。特に拝殿は、屋根を修理して壁や亀腹を塗り直し、飾り金物 を洗って箔を指し直すことが木部の洗いと共に行われており、これ らの修復行為によって、建物全体の美観が整えられ、洗いによって 木肌が明るく浄化された様を想起することができる。

\section{元禄九年（1696）法隆寺大湯屋表門修理工事における灰汁洗いと 「さ〉ら切わら」}

法隆寺の元禄修理仕椂帳には、修理に合わせて行われた「洗い」 についての仕様を確認することができる。破損修復一式請切入札仕 様根帳』(法隆寺 蔵) 元禄九年十二月の五冊の内三番には、大湯屋 · 大湯屋前四ツ足門・南大門等の修理仕様が掲載されている。この内 大湯屋前四ツ足門の項目には以下の記載がある。

一、大湯屋前 四ツ足門（以下割注）桁行壱間五尺八寸梁ま壱 間二尺七寸

(中略)

右之破損修復仕様

一、惣ゆかミ柱之高下ヲ直し柱根不朽様ニかへ共取掛リ水朽リ
申所有之候者禾品寸法古毛文取合根継致替可申候内之方四 ツ柱根沓二ツ朽リ候間寸法禾品完うう之く新木二而仕直シ 可申候事

一、唐居敷蹴放共朽申候間桧小節新木ヨ以寸法以前う之之取 替同所方立高六六七寸切上尔根継仕直し可申候事

一、冠木両鼻朽少有之候桧小節板厚一寸幅広一枚板二而四方木 口共包付釷三寸歩二打助可申候事

(中略)

一、同所壁妻いらかとも下地損候所仕直し裹表六反塗塗直し可 申候事下地白土こそけ落上塗仕様奥書二有之

(中略)

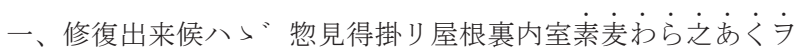
致さう官切わら户以何度も洗隅際々迄洗残少少も無之様二 念 7 入候事 小以代銀三百拾九斥四分 ${ }^{18)}$

[傍点筆者 $]$

文中の「大湯屋前四ツ足門」は法隆寺に現存寸る室町前期頃建立 の大湯屋表門を指している。法隆寺元禄大修理時に大湯屋と共に修 理を受けた際の修復仕様帳である。

柱のゆがみを全て直し、柱根に水腐れ等ある所は根継をし、柱根 沓 (木製の柱根巻の意か) を取替えとある。しかし「京品寸法古手 文取合」や「守法禾品完う亡之辸表現から、木品（木材の 材質・材種）や寸法は既存材に合わせて繕うという修理方針も明記 されている。また唐居敷と蹴放も新材で「以前うこ之く」取替えを し、冠木の両鼻の朽損部は四方と木口を板で包むといった処理も記 載されている。さらに妻壁は薨 (いらか) 部分も含め損傷下地の部 分は塗り直し、白土をこそげ落として上塗りを奥書の仕様の通りに 行うとしている。

そして、全体の修復が終了した後、全ての見え掛り部分を屋根裏

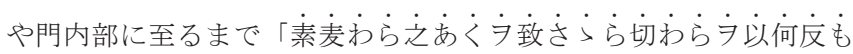
洗」とある。これにより、麦葍の灰汁を洗いに使用したことが分か る。また延暦寺寬文修理にも見られた「切わら」の他に「さ〉ら」 が明記されている。これらは、木肌を物理的に擦るために用いられ たものと考えられ、䇺と切㩰に麦葍の灰汁を付けて擦るという当時 の洗いの方法を推察することができる。そして「隅際々迄洗残少少 も無之様二念ヨ入」から、隅々まで念を入れて洗いを行う方針であ ったことが伺える。また、本書には塗装の記述は無く、現状の大湯 屋表門自体にも塗装痕は確認されていないため、塗装の無い白木の 門として修理が行われていることが分かる。このため、建立後三百 年以上の年月を経た白木の門を修理し、壁を塗り直して念入りに洗 いをかけ、門の視覚的印象を新築に近づける工事であったことが伺 える。しかし、修理方針はあくまで材質・寸法を古材に合わせる等、 現代の保存修復に近い修理方法が採用されている点も注目される。

\section{元禄四年 (1691) - 元禄十年 (1697) 法隆寺聖霊院 · 三経院修理工事 における「洗方」と「南都洗屋八右衛門」}

法隆寺の元禄修理関連文書は、先に挙げた『破損修復諸色一式請 切入札仕様根帳』の他、工事施工業者への支払い記録である勘定帳 等も残されている。元禄三年以後に行われた伽藍の修復工事の支払 い記録である『正徳二年 元禄三年より 伽藍修復惣勘定帳控』(法 
隆寺 蔵）には、元禄四年（1691）から五年に行われた法隆寺聖霊 院の修理支払代金が記録されている。

元禄四年暦辛未勘定之覚

一 一貫目聖霊院修復方大工安兵衛渡

元禄五申暦勘定之覚

一 二百五十多洗屋方

但聖霊院三経院等洗方也（以下略） ${ }^{19}$

[傍点筆者］

現存する法隆寺聖霊院は、弘安七年 (1284)の再建とされており、 内陣に聖徳太子像を祀る漆塗りの厨子が造り付けられた仏堂である。 また三経院は寛喜三年（1231）の再建として現存しており、両建物 は後方に僧坊を付した切妻妻入建物で、西院回廊を挟んで対を成し ている。

聖霊院は元禄四年 (1691) に正面の部戸を取り替える等の修理が 行われており、その勘定記録として修復方大工安兵衛の名が記され ている ${ }^{20)}$ 。そして翌元禄五年（1692）の覚書に「二百五十斥 洗屋 方 但聖霊院三経院等洗方也」の記載を見ることができる。前年の 修復工事完了に合わせ、聖霊院と三経院に洗いをかけたと読み取れ る。「洗屋方」「洗方」の記述により、元禄五年の時点で洗いを専門 とした業者への支払いがあったことが確認できる。「二百五十斥」の 金額から、洗いは「一貫目」の工費であった大工仕事のおよそ四分 の一程度（三経院と合わせた金額であるため一棟当たりで換算する と八分の一程度）以下の工費であったことが読夕取れるのである。 しかしながら、本史料はあくまで正徳二年（1712）における過去帳 の控えであるため、元禄四年の段階で「洗屋」「洗方」という呼び方 があったのかはこの記述からは必ずしも断定できない。

さらに法隆寺伽藍全体に及んだ元禄八年 (1695) から十一年にか けての修復工事が始まり、聖霊院や三経院西室等も再び工事が行わ れている。当時の修理支払い記録となる元禄十年日付の『修理方惣 勘定帳』(法隆寺 蔵) には以下の記載がある。

$$
\begin{gathered}
\text { 二十二貫八百二十四多八分六リン 井筒屋 七郎兵衛江 } \\
\text { 但諸堂二十ケ所請負総払也 } \\
\text { 一十七貫四百六十三多四分八厘 石 屋 六兵衛江 } \\
\text { 但諸堂石段雁木石垣等二十ケ所請負惣銀也 } \\
\text { 一 三貫二百六十三多七厘 錺 屋 宇左衛門 } \\
\text { 但塔金堂雨打金物聖霊院軒廻リ一切経蔵 } \\
\text { 上宮王院錺勧学院釬隠等 }
\end{gathered}
$$

(中略)

$$
\begin{aligned}
& \text { 一 五百九十四多一分三リン 塗師 源兵衛等四人 } \\
& \text { 一 九十四多三分五リン新町 岩右衛門 } \\
& \text { 但聖霊院内陣材木東室之板敷之板等代 } \\
& \text { 一 四百六十目南都洗屋 八右衛聞 } \\
& \text { 但聖霊院大床洗三経院内陣洗代 } \\
& \text { 一 八百九十目八分七リン鍛冶屋 平兵衛 } \\
& \text { 但西円堂聖霊院三経院等十余方所瓦釬鬼釣等 } \\
& \text { 鉄物仕足代也（後略） }{ }^{21)}
\end{aligned}
$$

[傍点筆者 $]$

まず元禄修理諸堂請負の総支払いとして井筒屋七郎兵衛 ${ }^{22)}$ への支 払いが記載され、石、飾金物の諸堂の支払い金額が明記されている。
また、聖霊院の宮殿（厨子）と講堂の長押釘隠し・礼盤の漆仕上を 塗師 4 名が行っている。

そして「四百六十目 南都洗屋 八右衛門」により、南都（奈良） の洗い屋八右衛門という人物に四百六十目の支払いがあったことが 見て取れる。「但聖霊院大床洗三経院内陳洗代」より、聖霊院は大床 を洗い、三経院は内陣を洗ったものと考えられる。

さらに、同元禄十年（1697）の『諸伽藍普請金銀緒拂帳』（法隆

寺 蔵）にも、同様に洗い屋の記録を確認することができる。

十七日

一 五百五十目 聖霊院西円堂上宮王院

修復方請負銀高内借

井筒屋 七郎兵衛一渡 請取有之

同日（七月九日）

$$
\begin{array}{ll}
\text { 一 百三十目 聖霊院御拝妻高欄 } \\
\text { 洗方請負銀内借 } \\
\text { 南都洗や 八右衛門へ渡 請取有之 }
\end{array}
$$

(中略)

$$
\begin{aligned}
& \text { 同（十二月二十五日） } \\
& \text { 一百五十目聖霊院西円堂上宮王院 } \\
& \text { 七郎兵衛請負方 } \\
& \text { 左官八右衛門へ 請取有之 } \\
& \text { 高欄蟬色塗代 } \\
& \text { 郡山漆屋六左衛門 請取有之（後略）23) }
\end{aligned}
$$

井筒屋七郎兵衛への聖霊院修復請負代金の他、「南都洗や八右衛 門」への代金百三十目が記載されている。「聖霊院御拝妻高欄」は、 聖霊院の向拝を含む妻側の高欄を洗ったという意味であろう。『修理 方惣勘定帳』に書かれていたのは「聖霊院大床」であり、大床と呼 ばれる正面の縁板洗いとは別に、高欄にも洗いをかけて別途支払い を行ったものと思われる。また、『修理方惣勘定帳』にも記載されて いた「南都洗屋 八右衛門」の名前があり、同一の業者を示してい るものと思われる。そして、聖霊院宮殿（厨子）の高欄に蝋色塗が 行われ、漆屋六左衛門への支払いが記録されている。聖霊院は、元

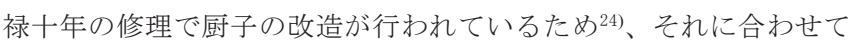
漆仕事が行われたと考えられる。聖霊院と三経院には、共に内陣に 漆仕上の厨子や仏壇、一部建具が存在するが、それ以外の主要軸組 や外観への塗装痕は確認されていない。このことから、元禄修理に おいて洗いの記録がある聖霊院、三経院、そして前述した湯屋表門 も、元禄修理時には主要軸組や外観に塗装の無い建物として修理さ れ、洗いが行われたと考えられる。

\section{元禄十四年 (1701) 北野天満宮諸堂修理工事の「灰汁湯」洗い}

北野天満宮社殿は、慶長十二年（1607）豊臣秀頼による造営で、 権現造で知られる社殿が現存している。元禄十四年（1701）には、 境内全域に及ぶ諸堂の修復工事が行われており、入札目録や入用目 録、勘定帳が残され、当時の修理工事仕様の詳細が記録されている。 この中で、『元禄十四年北野天満宮并諸末社堂舎修復諸色入用銀高目 録帳』(北野天満宮 蔵) には、諸堂の修理に合わせて洗いを行う修 
理仕様が記されている。この内、本殿の修復仕様を以下に記す。 銀十二貫五十八氿分五厘 御本社附西庇共諸色御入用 右之御修復仕様、屋根桧皮莫一式莫直、軒硕手鉄物古キを用、 不足八仕足、箱棟鬼板共朽仕直、(中略) 其外繕仕廻りはめ板（割注略）一式仕直シ、同上小壁乱ま三 ま(割注略) 柑子縁損シ繥緑青塗胡粉塗彩色仕直如元二取付、 同外側地覆長押取替、腰長押之雨覆取替、惣内外廻的自江掛 り庆汁湯二而悉洗、木口はり仕、床下饅頭形塗直、北東上り 石かんき二ケ所雨落葛石共高下直シ候共、諸色請切二申付候、 委細者御勘定帳二御座候、(後略) 25)

[傍点筆者 $]$

主な修理内容は、檜皮屋根の葺き替え、落縁や高欄・鴨居長押等 の取替と各部締め直し、床下・石材修理等が挙げられる。また妻破 風小壁や蟇股に施された彩色の塗り直し、殿内鴨居長押敷居の真塗 や高欄の漆塗り補修、錺金物の修復の他、欄間建具の塗装補修も記 されている。しかし北野天満宮の本殿は上記した細部彩色以外に、 主要軸組部の丹塗り等の塗装が無い建物である。文中に部分彩色に 関する記述があっても軸組塗装の記述が無い点からも確認するこ とができる。このため、「惣内外廻り見江掛り庅汁湯二而悉洗」と して、全ての見え掛りの白木の木肌部分には洗いをかけることが明 記されている。洗いには「灰汁湯」が使用されており、灰汁を温め る、または灰を煮出す等して、灰汁洗いを行う仕様を指示している のが見て取れる ${ }^{26)}$ 。

また、本史料は上記した本社殿の他、幣殿、拝殿、東西楽の間、 舎利門等の主要施設の修復を始め、絵馬掛所や雪隠等諸設備の新造、 小屋掛竹垣等の設置まで 66 に及ぶ項目が計上されている ${ }^{27)}$ この内 約 40 項目には本殿修復仕様と同様に「見江掛り灰汁湯二而悉洗」「灰 汁湯二而悉洗」の記載が確認でき、修復した建造物の多くに洗いを 行う方針であったことが分かる。このため、境内建物全体を修復し、 屋根を莫き替え、細部彩色の塗替えと共に、経年により黒ずんでい た主要軸組木部見え掛りに洗いをかけて、建物全体を健全化すると 共に清浄に明るく見せることが工事の目的だったと考えられる。こ のようにして、檜皮莫の入母屋屋根に白木の軸組、正面千鳥破風や 組物と欄間建具等に鮮やかな彩色が施された、建立時の明るく軽や かな様相に近づけるための洗い仕事が計画されていたと推察される。

天明四年 (1784) 大徳寺興臨院客殿修理工事の「洗方」と専用足場 大徳寺興臨院本堂は、天文年間から永禄頃 $(1532 \sim 1569)$ 建立と される方丈建築である。『興臨院客殿屋根南平東妻莫替并諸普請納下 帳』(大徳寺興臨院 蔵) には、開祖二百五十年忌に合わせて天明四 年 (1784) から五年 (1785) にかけて行われた修理記録の詳細が記 されており、一部洗いを行った記録が記されている。

(前略)

\begin{tabular}{|c|c|}
\hline 七百九十一斥四分 & 大工百九十五人（中略） \\
\hline $\begin{array}{l}\text { 内 五十四人半 } \\
\text { (中略) }\end{array}$ & 客殿庇縁張替 \\
\hline $\begin{array}{c}\text { 五百二拾五多八分五厘 } \\
\text { 但麩糊薪物足代此外世 }\end{array}$ & 左官方渡切分 平右衛門註文 \\
\hline $\begin{array}{l}\text { 内二百六十六多五分 客 } \\
\text { 塗白土一式 }\end{array}$ & 客殿表三間衣鉢閣并南表縁玄関迄砂摺中 \\
\hline
\end{tabular}

（中略）

五百四十六多二分五厘畳屋 久兵衛註文

但客殿五十畳表替大書院替畺裏客殿眠蔵茶堂合二十一帖半長床 三十四枚刺手間等

(中略)

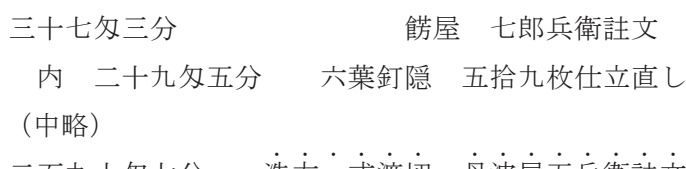

二百九十多七分 洗方一式渡切 舟波屋主兵衛註文

内 百五十六多四分 客殿表主間衣鉢閣南表縁側迠洗足場縄代共 四十八多一分 玄関用（後略） ${ }^{28)}$

[傍点筆者 $]$

現在本堂と呼ばれている客殿の縁庇の張替えや庫裏・縁側床板の 修理が行われている他、玄関も建具の張替えや根継ぎが行われてい る。また左官屋、畳屋、餝屋等が仕事をしており、各々の工事仕様 と金額が明記されている。左官の内訳に「客殿表三間衣鉢閣并南表 縁玄関迄」の記載があることから、客殿表三間と衣鉢の間・南表縁 と玄関の壁を下地から塗り直したと読み取れる。そして「洗方二式 渡切 舟波屋主兵衛註文」として二百九十多七分の支払い金額が明 記されている。その内訳は「客殿表忈間衣鉢閣南表縁側迠洗」に百 五十六多四分、「玄関用」に四十八多一分の記述が見られ、左官の内 訳にあった壁塗替え範囲と全く同じ場所に洗いが行われているのが 分かる。洗い工事小計二百九十多七分の残り八十六多一分の内訳は 翻刻者により省略されているため不明であるが、修理が行われた表 三間と表縁側、玄関等、人目に付きや寸い間取りの主要部分に、優 先的に洗いと壁の塗替えが行われたものと考えられる。

また、修理項目の職種毎に支払い金額が記され、「左官方渡切分 平右衛門註文」や「畳屋 久兵衛註文」「餙屋 七郎兵衛註文」に見 られるように、各職種の下に記されているのは工事を担当した業者 を指していると考えられる。このため「洗方一式渡切 舟波屋主兵 衛註文」から、「丹波屋五兵衛」は洗い屋の名前を示している可能性 がある。そして、洗い工事と左官工事が別々に記されている事から、 天明期の京都においても洗いが左官から独立した業務として工事請 負が行われていた事を読み取ることができるのである。

\section{天保七年（1836）知恩院諸堂修復工事における「灰汁湯洗」と「拭 洗」と「拭ふき」}

知恩院では、文政十三年（1830）に京都で発生した地震の災害復 旧工事として、天保六年（1835）に大小方丈・集會堂・大小庫裏等 の修復が行われている。『知恩院諸堂社其外修覆諸色代銀請取帳』(知 恩院 蔵）はその際の積算書である ${ }^{29}$ 。なお、ここで修理対象となっ た諸堂は主に寛永十年（1633）の災後の再建であった。以下に集 會堂修理における洗いの記録を以下に示す。

一 集會堂 梁行十二間七寸 桁行二十一間六尺（中略） 右御修復仕様（中略）

内廻的拭字き外廻り両妻共灰汁湯洗仮粧木道具木口胡粉塗直、 掛魚之六葉真塗仕直（中略）

式台上り段両脇羽目共取付直繋鉄物損繥虹梁知木仮粧禾道具庅 汁湯洗木口胡粉塗直掛魚之六葉真塗菊座金筞置直 (中略) 
洗方

四方屋根裏二軒繋垂木虹梁雲板大桁大斗

肘木広縁羽目板拭板正面唐戸格子戸障子共有之 内外廻り

一 八十二坪二分 庆汁湯洗 軒高一丈九尺九寸分一丈一尺迄 集會堂廻ノ庅汁湯洗

代銀三百二十八办八分 但 洗方定代諸品共一式 建坪一 坪付四多

\section{屋根裏板垂木茅負裏甲両妻破風}

二重虹梁升形肘木掛魚羽目板共有之 軒迴り

一 三十八坪六分三厘 灾汁湯洗 右同断

代銀百四十六多七分九厘 但 右同断 建坪一坪付三办八分

屋根裏 $\square$ ばら木迴物柱 長押天井拭板等有之 内外廻り

一 三拾四坪五分 拭洗 ${ }^{30)}$ 右同断

代銀七十一办四分一厘 但 右同断 建坪一坪付二多七厘

丸柱猿頬天井長押 化粧貫共有之 内廻り

一 二百六十四坪九分九厘 拭字き31) 右同断

代銀三十七多一分 但 右同断 一坪付一分四厘

洗方

銀 五百八十四多一分 請負之 鍵屋次兵衛 ${ }^{32)}$

[傍点筆者 $]$

本史料の構成は、前半に建物名と規模が示され、木工事から屋根・ 金物・建具などの修復仕様の詳細が文章で記され、後半に大工手間・ 材木方・鍛冶方・屋根方・壁方・塗師方など職種ごとの必要材料と 金額が記される。この中に洗いの仕様も明示され、独立した職種と して「洗方」の項目があり、施工と金額の詳細が記録されている。

まず前半の仕様には「内廻り拭字き外廻り岀妻共庆汁湯洗」つま り集會堂の内周り（屋内）が「拭いふき」、外周り（屋外）が「灰汁

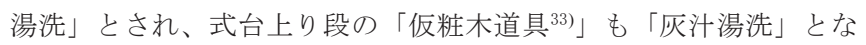
っており、場所により異なる仕様が書かれているのが確認できる。

さらに「洗方」の見積内訳を見ていくと、筆頭に四周に設けられ た広縁軒裏の繁垂木・虹梁・大斗肘木などの化粧木部と、建具や床 板を含む木部全般が計上され「灰汁湯洗」と記載されている。「洗方 足代諸品共一式 建坪一坪付四多」により、洗いの足場代と用途物 一式で、坪単価が四多であることが分かる。

次いで屋根裏板・垂木 ・ 茅負 ・ 裏甲と、両妻破風の二重虹梁・妌 形肘木・㱏魚・羽目板など、屋根周りの木部が計上され、同じく「灰 汁湯洗」と記される。「右同断 建坪壱坪付三多八分」とあり、こち

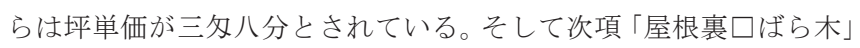
とあるのは、「まばら木」であろうか、集會堂西側にある玄関周りの 垂木を本屋根の繁垂木の対語として使用しているのかもしれない341。 ここで計上されている面積は比較的大きいため、内外の「柱長押天 井」は広縁のものを意味していると推察される。これは坪単価三多 八分で「拭洗」とある。

最後に、集會堂内部の丸柱・猿煩天井・長押・化粧貫に関しては 「拭ふき」と記載され、坪単価は一分四厘が計上されていた。

以上のように、施工する部位によって洗いの種別が「灰汁湯洗」 「拭洗」「拭尔き」と三種に分かれ、さらにその単価は「灰汁湯洗」 を二段階にすることで四段階に分かれていたことが分かる。灰汁湯 洗」は前述した北野天満宮同様、「灰汁」と「湯」が薬液に用いられ た洗いである。湯を用いることで高い洗浄効果が期待できる灰汁洗
いが、広縁内外の化粧木部と、外観に関わる屋根周りの化粧木部に 用いられている。また、見積金額に「洗方定代諸品共一式」(次項よ り「右同断」）とあるため、「足代」つまり足場代が計上されている ことが分かる。しかし本史料には「洗方」の後に「損料物方」があ り、「軒足代」「天井足代」「破風足代」「須屋根」等が計上されてお り、特に屋根周りの足場は木工事や瓦工事と兼用可能だったと推測 される。したがって「洗方定代」は洗い専用の足場であり、「灰汁湯 洗」の広縁周りと屋根周りの坪単価の二分の減額は、この足場の有 無による違いである可能性が高い。もしくは、広縁周りの方が近距 離で人の目に触れるため、より丁寧な仕事が求められた可能性も考 えられる。次に「拭洗」であるが、「ぬぐいあらい」と読むものと考 えられ、「灰汁」の文字が無いため、灰汁を用いずに水等で洗い、布 などで拭い取るという仕様であったか、水を多めに含ませた布など で洗うように拭っていく仕様であった可能性も考えられる。坪単価 は「武多七厘」で「灰汁湯洗」の満額 4 多のほぼ半值である。そし て「拭ふき」は「ぬぐいふき」であり、「洗」の言葉が無いため、水 で濡らした布を固く絞った水拭きか、乾拭きであった可能性が考え られる。坪単価は「一分四厘」で、「拭洗」の約 15 分の 1 であった。

また、最後に洗方の合計金額が記され、請負人に「鍵屋次兵衛」 の名が記されているのも注目される。本史料の最末尾には各職方の 請負人一覧が書かれているのだが、洗いに関しては「小川通竹屋町 上ル町 手伝方 中日雇方 翠策方 疊方 小買物方 洗方 損料 物方 請負人 鍵屋治兵衛 $\left.{ }^{35}\right\rfloor$ とあり、小川通竹屋町上ル町の鍵屋 次兵衛が、洗方と合わせ手伝方・中日雇方・翠䇥方・畳方等という 比較的細かい職種を一手に請け負っていたことも分かる。このため、 鍵屋治兵衛は洗い屋ではなく、工事の部分発注を請け負った商人で あったと考えられる。

なお、本論における『知恩院諸堂社其外修覆諸色代銀請取帳』は 『国宝・重要文化財知恩院本堂及び集會堂ほか二棟修理工事報告書』 に集會堂部分のみ影印と共に翻刻掲載されているものを用いている。 このため本史料には、集會堂だけでなく、小庫裏・大方丈・小方丈 その他諸堂の修復内訳が記載されているが、集會堂以外の内訳は筆 者は未見である。しかし本報告書には諸堂舎費用の職種ごとの金額 が記されており、大方丈・小方丈その他の洗方の金額が合計 365 多 計上されている ${ }^{36)}$ 。このことから、天保七年 (1836) 知恩院諸堂修 復工事では、集會堂と共に大方丈・小方丈等を含む広範囲で洗いが 行われていたことも分かるのである。

\section{3. 近世文書にみる「洗い」の用途物}

以上、慶安二年 (1649) から天保七年 (1836) までの京都・奈良・ 滋賀における作事関係文書の洗いの記録を見てきた。これらの内容 を序文で示した史料も含めてまとめたものを Table1 に示す。以下、 洗いに用いられた薬液や道具などの用途物、施工者、洗いの仕様に ついての分析を行う。

本稿で示した近世史料に見られる洗いの用途物には、木肌を洗う 洗浄溶液とその原料、木肌を物理的に擦る道具、そして洗いを行う ための足場が組まれる事例も存在したことが分かった。

洗浄溶液として「灰汁」という言葉が明示されていたのは福王子 神社拝殿・法隆寺大湯屋表門・北野天満宮諸堂・知恩院集會堂であ った。特に元禄六年 (1693) 福王子神社拝殿の「そばがらのあく」、 
元禄九年法隆寺大湯屋表門の「素麦わら之あく」から、「そばがら (蕎麦殼)」または「素麦わら (惹麦葈) 」は木肌を洗う洗浄溶液で ある灰汁の原料であることが分かる。これは序文で示した南禅寺日 ノ門の「萫麦木」南禅寺祠堂の「蕎麦葍」にも見られ、植物種が「蕎 麦」と明記されていた。蕎麦の灰は稲葍灰等と比較しても高いアル カリ性を示すことが知られており ${ }^{37}$ 、高い洗浄性から洗いに有効と 判断され、近世の灰汁洗いに採用されていた可能性がある。

また、元禄十四年（1701）の北野天満宮諸堂と天保七年（1836） 知恩院集會堂では、灰汁の原料は明示されていないが「灰汁湯」が 指示されていた。これは灰汁を温める、または灰を煮出す等して、 灰汁を高温の状態で使用することで、より高い洗浄性を求める仕様 であったと考えられる。

木肌を洗うための道具の類が明記されたのは、寛文八年（1668） 延暦寺諸堂修復工事における洗いと、元禄九年（1696）法隆寺大湯 屋表門の洗いのみであった。延暦寺諸堂では木肌を擦る「切わら」
が、法隆寺大湯屋では「簷（ささら）」と「切葈」が灰汁とは別に 記されていた。現代においても伝統的な洗い仕事を行う職人は、竹 の皮を用いた「篰」と、葈やい草を束衫た篣を使用している ${ }^{38)}$ 。特 に「切わら」は木肌を擦る「水篣」や「灰汁引き」の原型を示して いると考えられる。この様な、現代に伝えられている伝統的洗い仕 事に通じる方法が、寛文から元禄年間にすでに行われていたことが 明らかとなった。

また、天明四年（1784）の大徳寺興臨院と天保七年（1836）の知 恩院集會堂では、洗い用の足場が記録されていた。通常建築修理工 事等の現場では屋根や建築内外の工事を行う職方と足場が共有さ れるものであるが、洗いは室内の天井や造作・軒廻り等、見え掛り の木部を隅々まで洗う必要がある。このため他の職種の足場で対応 できない場所や屋内の仕上げ等、污れを嫌う場所には、洗い専用の 足場が組まれたものと考えられる。

さらに、天保年間の知恩院諸堂には「洗方足代諸品共一式」とい

\begin{tabular}{|c|c|c|c|c|c|c|c|}
\hline $\begin{array}{l}\text { 記録年代 } \\
\text { Recorded } \\
\text { year }\end{array}$ & $\begin{array}{l}\text { 対象建造物 } \\
\text { Building name }\end{array}$ & $\begin{array}{l}\text { 史料名 } \\
\text { Document name }\end{array}$ & $\begin{array}{l}\text { 史料所藏機関 } \\
\text { The institution of } \\
\text { possess the } \\
\text { document }\end{array}$ & $\begin{array}{l}\text { 薬液・原料 } \\
\text { Washing } 1 \text { iquid } \\
\text { and raw material }\end{array}$ & $\begin{array}{l}\text { 用途物 } \\
\text { Equipment }\end{array}$ & $\begin{array}{l}\text { 施工者 } \\
\text { Workman }\end{array}$ & $\begin{array}{l}\text { 所作 } \cdot \text { 種別等 } \\
\text { Behavior, Classification, etc. }\end{array}$ \\
\hline $\begin{array}{l}\text { 慶長六年 } \\
(1601)\end{array}$ & $\begin{array}{l}\text { 大徳寺 } \\
\text { 真珠庵客殿 } \\
\text { Daitoku-ji } \\
\text { Shinjuan Temple }\end{array}$ & $\begin{array}{l}\text { 『真珠庵本坊東方江次 } \\
\text { 出作事小日記』 }\end{array}$ & $\begin{array}{l}\text { 大徳寺真珠庵 } \\
\text { Daitoku-ji } \\
\text { Shinjuan Temple }\end{array}$ & $\begin{array}{l}\text { 參升一合 营 } \\
3 \text { sho and } 1 \\
\text { gou of straw }\end{array}$ & - & - & $\begin{array}{l}\text { 客殿洗 } \\
\text { Arai for Kyakuden hall }\end{array}$ \\
\hline $\begin{array}{l}\text { 寛永十八 } \\
\text { 年 }(1641)\end{array}$ & $\begin{array}{l}\text { 南禅寺 日ノ門 } \\
\text { Nanzen-ji Temple }\end{array}$ & $\begin{array}{l}\text { 『南禅寺総門・脇門·北 } \\
\text { 門普請帳并風呂修補』 }\end{array}$ & $\begin{array}{l}\text { 南禅寺 } \\
\text { Nanzen-ji } \\
\text { Temple }\end{array}$ & $\begin{array}{l}\text { 蕎麦木 } \\
\text { Buckwheat } \\
\text { straw }\end{array}$ & - & $\begin{array}{l}\text { 左冠 } \\
\text { Plasterer }\end{array}$ & $\begin{array}{l}\text { 日ノ門洗手間 } \\
\text { Costs of Arai for Hino-mon gate }\end{array}$ \\
\hline $\begin{array}{l}\text { 慶安二年 } \\
(1649)\end{array}$ & $\begin{array}{l}\text { 大徳寺 龍光院 } \\
\text { 昭堂・客殿 } \\
\text { Daitoku-ji } \\
\text { Ryoukou-in Temp } \\
\text { le }\end{array}$ & $\begin{array}{l}\text { 『龍光院昭堂普請材木 } \\
\text { 帳』 }\end{array}$ & $\begin{array}{l}\text { 大徳寺 龍光院 } \\
\text { aitoku-ji } \\
\text { Ryoukou-in Temp } \\
\text { le }\end{array}$ & - & - & $\begin{array}{l}\text { 左官 } \\
\text { Plasterer }\end{array}$ & $\begin{array}{l}\text { 左官客殿洗手間 } \\
\text { Plasterer's costs of Arai for Kyakuden } \\
\text { hal1 } \\
\text { 昭堂拭手間 } \\
\text { Costs of wiping for Shoudou hall }\end{array}$ \\
\hline $\begin{array}{l}\text { 承応元年 } \\
\text { (1652) }\end{array}$ & $\begin{array}{l}\text { 南禅寺 } \\
\text { 祠堂之間 } \\
\text { Nanzen-ji Temple }\end{array}$ & $\begin{array}{l}\text { 『南禅寺祠堂·新門·経 } \\
\text { 蔵・倉司作事下行帳』 }\end{array}$ & $\begin{array}{l}\text { 南禅寺 } \\
\text { Nanzen-ji } \\
\text { Temple }\end{array}$ & $\begin{array}{l}\text { 蕎麦葍拾六束 } \\
6 \text { bunches of } \\
\text { buckwheat } \\
\text { straw }\end{array}$ & - & $\begin{array}{l}\text { 左冠 } \\
\text { Plas } \\
\text { terer }\end{array}$ & $\begin{array}{l}\text { 障子并雨戸洗 } \\
\text { Arai for Shoji and Amado shutters } \\
\text { 左冠洗手間 } \\
\text { Plasterer's costs of Arai }\end{array}$ \\
\hline $\begin{array}{l}\text { 寛文 } 8 \text { 年 } \\
(1668)\end{array}$ & $\begin{array}{l}\text { 延糜寺 } \\
\text { 諸堂 } \\
\text { Enryaku-ji } \\
\text { Temple }\end{array}$ & $\begin{array}{l}\text { 『御修復 伏見屋積帳 } \\
\text { 比耪山上上根山本中堂 } \\
\text { 迴廊文殊楼 大講堂 } \\
\text { 鐘撞堂』 }\end{array}$ & $\begin{array}{l}\text { 延暦寺 } \\
\text { Enryaku-ji } \\
\text { Temple }\end{array}$ & - & $\begin{array}{l}\text { 切わら } \\
\text { Straw brush }\end{array}$ & - & $\begin{array}{l}\text { 諸々の堂内外ともに楽事致し所切わらにて } \\
\text { 念を入洗可申事 Wash carefully using straw } \\
\text { brush at the inside and outside of halls } \\
\text { where events are held }\end{array}$ \\
\hline $\begin{array}{c}\text { 元禄六年 } \\
\text { (1693) }\end{array}$ & $\begin{array}{l}\text { 福王子神社 } \\
\text { 择殿 } \\
\text { Fukuouji Shrine }\end{array}$ & $\begin{array}{l}\text { 『仁和寺諸堂社御修復 } \\
\text { 仕様入札帳』 }\end{array}$ & $\begin{array}{l}\text { 仁和寺 } \\
\text { Ninna-ji Temple }\end{array}$ & $\begin{array}{l}\text { ぞ゙がらのあ } \\
< \\
\text { Lye from } \\
\text { buckwheat } \\
\text { hulls }\end{array}$ & - & - & $\begin{array}{l}\text { 共一式そばがらのあくを以洗拭可申候事 } \\
\text { Wash and wipe all parts with lye from } \\
\text { buckwheat hulls }\end{array}$ \\
\hline $\begin{array}{l}\text { 元禄九年 } \\
(1696)\end{array}$ & $\begin{array}{l}\text { 法隆寺 } \\
\text { 大湯屋表門 } \\
\text { Horyu-ji Temple }\end{array}$ & $\begin{array}{l}\text { 『破損修復諸色一式請 } \\
\text { 切入札仕様根帳』 }\end{array}$ & $\begin{array}{l}\text { 法隆寺 } \\
\text { Horyu-ji Temple }\end{array}$ & $\begin{array}{l}\text { 素麦わら之あ } \\
< \\
\text { Lye from } \\
\text { buckwheat } \\
\text { hulls }\end{array}$ & $\begin{array}{l}\text { さ〉ら切わら } \\
\text { Sasara brush and } \\
\text { scourer made of } \\
\text { rice straw }\end{array}$ & - & $\begin{array}{l}\text { 素麦わら之あくヨ致さ〉ら切わらヨ以何反 } \\
\text { 洗隅際々迄洗残リ少も無之様二念习入申 } \\
\text { 候事 } \\
\text { Wash every corner carefully using Lye from } \\
\text { buckwheat hulls with sasara whisk and } \\
\text { straw brush so that there is no unwashed } \\
\text { parts }\end{array}$ \\
\hline \multirow[t]{2}{*}{$\begin{array}{l}\text { 元禄十年 } \\
(1697)\end{array}$} & \multirow[t]{2}{*}{$\begin{array}{l}\text { 法隆寺 } \\
\text { 聖霊院・経院 } \\
\text { Horyu-ji Temple }\end{array}$} & 『修理方惣勘定帳』 & $\begin{array}{l}\text { 法隆寺 } \\
\text { Horyu-ji Temple }\end{array}$ & - & - & \multirow{2}{*}{$\begin{array}{l}\text { 南都洗屋(や) } \\
\text { 八右衛門 Nanto } \\
\text { Arai-ya } \\
\text { Hachiuemon }\end{array}$} & $\begin{array}{l}\text { 聖霊院大床洗三経院内陳洗代 } \\
\text { Costs of Arai for floor on veranda of } \\
\text { Shouryouin hall and naijin of Sangyouin } \\
\text { hall }\end{array}$ \\
\hline & & $\begin{array}{l}\text { 『諸伽藍普請金銀諸拂 } \\
\text { 帳』 }\end{array}$ & $\begin{array}{l}\text { 法隆寺 } \\
\text { Horyu-ji Temple }\end{array}$ & - & - & & $\begin{array}{l}\text { 洗方請負 } \\
\text { Arai-kata workmen's contract }\end{array}$ \\
\hline $\begin{array}{l}\text { 元禄十四 } \\
\text { 年 }(1701)\end{array}$ & $\begin{array}{l}\text { 北野天満宮諸堂 } \\
\text { Kitano tenman-gu } \\
\text { Shrine }\end{array}$ & $\begin{array}{l}\text { 『元禄十四年北野天満 } \\
\text { 宮并諸末社堂舎修復諸 } \\
\text { 色入用銀高目録帳』 }\end{array}$ & $\begin{array}{l}\text { 北野天満宮 } \\
\text { Kitano } \\
\text { tenman-gu } \\
\text { Shrine }\end{array}$ & $\begin{array}{l}\text { 灰汁湯 } \\
\text { Hot lye }\end{array}$ & - & - & $\begin{array}{l}\text { 惣内外廻見江掛り灰汁湯二而悉洗 } \\
\text { Wash all the visible parts inside and } \\
\text { outside of the building with the hot lye }\end{array}$ \\
\hline $\begin{array}{l}\text { 正徳二年 } \\
\text { (1712) } \\
\text { ※元禄四 } \\
\text { 年 }(1691) \\
\text { の控 }\end{array}$ & $\begin{array}{l}\text { 法隆寺 } \\
\text { 聖霊院·三経院 } \\
\text { Horyu-ji Temple }\end{array}$ & $\begin{array}{l}\text { 『正徳二年 } \text { 元禄三年 } \\
\text { より伽藍修復惣勘定 } \\
\text { 帳控』 }\end{array}$ & $\begin{array}{l}\text { 法隆寺 } \\
\text { Horyu-ji Temple }\end{array}$ & - & - & $\begin{array}{l}\text { 洗屋方 } \\
\text { Arai-ya-kata } \\
\text { workmen } \\
\text { 洗方 Arai-kata } \\
\text { workmen }\end{array}$ & $\begin{array}{l}\text { 聖霊院三経院等洗方也 } \\
\text { Arai for Shouryouin hall and Sangyouin } \\
\text { hall }\end{array}$ \\
\hline $\begin{array}{c}\text { 天明四年 } \\
(1784)\end{array}$ & $\begin{array}{l}\text { 大徳寺興臨院 客 } \\
\text { 殿 } \\
\text { Daitoku-ji } \\
\text { Korinin Temple }\end{array}$ & $\begin{array}{l}\text { 『興臨院客殿屋根南平 } \\
\text { 東妻葷替并諸普請納下 } \\
\text { 帳』 }\end{array}$ & $\begin{array}{l}\text { 大徳寺興臨院 } \\
\text { Daitoku-ji } \\
\text { Korinin Temple }\end{array}$ & - & $\begin{array}{l}\text { 足場縄 } \\
\text { Scaffolding and } \\
\text { ropes }\end{array}$ & $\begin{array}{l}\text { 洗方 } \\
\text { Arai-kata } \\
\text { workmen }\end{array}$ & $\begin{array}{l}\text { 客殿表三間衣鉢閣南表縁側迠洗 } \\
\text { Wash the front of three rooms, a Ehatsukaku } \\
\text { room and southern veranda of Kyakuden } \\
\text { hall }\end{array}$ \\
\hline $\begin{array}{l}\text { 天保七年 } \\
\text { (1836) }\end{array}$ & $\begin{array}{l}\text { 知恩院 集會堂 } \\
\text { Chion-in Temple }\end{array}$ & $\begin{array}{l}\text { 『知恩院諸堂社其外修 } \\
\text { 覆諸色代銀請取帳』 }\end{array}$ & $\begin{array}{l}\text { 知恩院 } \\
\text { Chion-in Temple }\end{array}$ & $\begin{array}{l}\text { 灰汁湯 } \\
\text { Hot lye }\end{array}$ & $\begin{array}{l}\text { 洗方足代諸品共 } \\
\text { 一式 } \\
\text { Complete set of } \\
\text { scaffolding and } \\
\text { equipment for } \\
\text { Arai }\end{array}$ & $\begin{array}{l}\text { 洗方 } \\
\text { Arai-kata } \\
\text { workmen }\end{array}$ & $\begin{array}{l}\text { 灰汁湯洗 Arai with hot lye } \\
\text { 拭洗 Arai by wiping } \\
\text { 拭ふき Wiping }\end{array}$ \\
\hline
\end{tabular}


う記述がみられた。この表現からは、「諸品」の詳細こそ明記され ていないが、洗い工事に必要な足場代や薬液等を含む諸用物がすで に確立されており、洗い仕事の坪単価の決定にも寄与していたであ ろうことを物語っている。

\section{4. 近世文書にみる「洗い」の施工者}

次に近世史料から読み取られる事項から、洗いの施工者と「洗い 屋」の存在について考察していく。

序文で示した寛永十八年（1641）の南禅寺日ノ門と、承応元年 （1652）の南禅寺祠堂の間、そして慶安二年（1649）大徳寺龍光院 昭堂では、洗い仕事は左官職人が、壁塗りの仕事と共に行っていた。 拙論で指摘した通り、左官と洗い仕事には「チリ掃除」や酸による 染み抜き等技術的な共通点が多く、兼業が容易であったと考えられ る ${ }^{39}$ 。したがって、南禅寺祠堂の間の作事下行帳が書かれた承応元 年までの京都においては、「洗い屋」という専門業者は未だ存在して いなかった可能性が高い。

しかし、正徳二年（1712）に書かれた法隆寺の支払い受取記録か らは、元禄五年（1692）に聖霊院と三経院に洗いがかけられ、洗い 仕事への支払いがあったことが確認できる。さらに元禄十年 (1697) 法隆寺の『修理方惣勘定帳』には「南都洗屋 八右衛門」そして元禄 十年（1697）六月日付の『諸伽藍普請金銀緒拂帳』にも「南都洗や 八右衛門」の記述が確認できた。また同史料には「左官八右衛門」 一別途支払いがされており、洗いが左官業と分離していることも確 認できる ${ }^{40)}$ 。元禄年間の法隆寺工事においては「洗屋」と呼ばれる 専門の洗い職が、洗い工事を独自に請け負っていたことが分かるの である。また「南都」は奈良を指すため、奈良において独立した洗 い業者が元禄年間には成立していたと言えるだろう。また単に地名 を示しているのではなく「南都洗屋」という洗屋の店名もしくは屋 号を名乗って商売を行っていた可能性も考えられる。

そして天明四年 (1784) の大徳寺興臨院客殿では、「洗方一式渡 切丹波屋五兵衛註文」の記述を見ることができる。丹波屋五兵衛」 は同史料中にある他の職種との比較から、洗い屋の名称である可能 性がある。また、法隆寺の元禄修理同様、「左官方」へ別途支払いが 行われており、洗いが左官業と分離しているのも確認できる。この ことから、天明年間には京都においても独立した洗い業者が存在し ていたと考えられる。しかし法隆寺の元禄修理に見られるように「洗 屋」と明記されていないため、「丹波屋」は洗い以外の仕事も行う業 種である可能性を残している。

さらに天保七年（1836）知恩院諸堂でも、同様に「洗方」が「壁 方」「塗師方」とは別の職種として明記されていた。なお、洗い工事 の「請負人」として記された「鍵屋次兵衛」は、手伝方・畳方・損 料物方などの比較的細かい職種について、洗方と合わせて工事を請 け負う商人の一人であった。

以上のことから、左官屋が壁塗りと共に洗いを請け負っていた南 禅寺祠堂工事の承応元年（1652）から、「南都洗屋」の工事項目が 記される元禄九年 (1696) 法隆寺伽藍修理までの間に、洗い屋とい う専門職が発生したと考えられる。南禅寺真珠庵客殿や大徳寺等に 見られる様に、近世初期において古建築の洗いに対する需要があつ たことは明確であるため、専門の職業が生まれる土壌はすでにあっ たと推察される。また南禅寺祠堂工事は京都、法隆寺伽藍修理は奈
良であるため、洗い屋の発生に地域差があった可能性も考えられる。 以上見てきた施工者の事例は、法隆寺を除いて全て京都の記録であ ったため、洗い仕事はむしろ京都で多く行われていたと見ることも できる。しかし、前掲のように、少なくとも元禄五年（1692）の奈 良において洗い屋は存在しており、元禄年間に「南都洗屋」として 洗い業を専門に請け負っていたことは、記録により確認することが できるのである。

なお、史料が少ないため明確な傾向とは言いがたいが、洗いの施 工者が明記されていなかった寛文年間以降の記録（延暦寺諸堂、福 王子神社帱殿、法隆寺大湯屋表門、北野天満宮諸堂）は、すべて塗 装の修復または塗り替えが併記された史料であった。塗師も、左官 と同様に漆や顔料が無塗装部分に付着した際の染み抜きや下地洗 い・砥の粉を用いた下地処理等の技術を持っている ${ }^{41)}$ このため、 洗いの施工者が明記されておらず、かつ塗師職が入る工事では、塗 師が洗いを行っていた可能性が考えられる。一方、本論中で「左官」 が洗いを行っていた三点の史料には、塗師の併記は見られなかった。 また、「洗屋」「洗方」等の洗いの専門職が明記された史料では、元 禄年間の法隆寺聖霊院と、天保年間の知恩院に塗師職・左官職との 併記があった。あくまで推測に過ぎないが、洗い屋の成立以前は、 塗師関係の作業が同時に行われた工事では塗師職が洗いを行い、左 官仕事が同時に行われた白木建物では左官が洗いを行っていたが、 元禄年間頃に独立した洗い屋が現れて、法隆寺聖霊院に見られるよ うな、塗師・左官・洗屋という職方の分業が行われるようになった のかもしれない。

また、「手伝」と呼ばれる工事の雑用を行っていた職種や42)農閑期 の百姓 ${ }^{43)}$ が、洗いに参入する可能性も考えられる。しかし、白木の 木肌は灰汁洗だけではアルカリ焼けを起すため、中性化のために酸 洗いを行う必要がある。さらに、土壁や手垢污れは酸洗い、経年や 煤污れは灰汁洗いといった、污れの種類による薬液の使い分けも必 要である。これらの技術について、管見では古記録での確認はでき ておらず、一種の口伝だったと考えられる。そして、このような知 識は、元は左官や塗師が持っていた経験知であったため、洗いは、 成立当初は容易に他の職種が参入しづらい技術であったと筆者は考 えている。このため、上記のような経験知の無い職種が洗いに参入 することがあったとすれば、それは、洗い屋成立後ある程度技術が 確立し、職人人口が増加した時期、例えば天保年間の知恩院に見ら れるような、大規模で専門的な洗い仕事が行われるようになってか らではないだろうか。

\section{5. 近世文書にみる「洗い」の所作と種別}

次に、これまでの史料検討から、「洗い」の種別と所作についてみ ていく。慶安二年（1649）の大徳寺龍光院昭堂では、既存の客殿に 対する「洗手間」に加え、新築された昭堂の仕上げ拭きと考えられ る「拭手間」が計上されていた。寛文八年 (1668) 延暦寺諸堂では、 塗装のある建物内外を「切わらにて念を入洗」という仕様が記され ていた。元禄六年 (1693) の福王子神社拝殿では「そばがらのあく を以洗拭」のように、灰汁で洗ったのちに「拭う」行為が明記され ている。元禄九年（1696）法隆寺大湯屋表門では「素麦わら之あく 习致さ〉ら切わら 入」とあり、門の木部を隅々まで念を入れて洗うために道具類も明 
示した詳細な仕様が記される。そして元禄十四年（1701）北野天満 宮諸堂では「惣内外廻り見江掛り灰汁湯二而悉洗」の記載から、建 物内外の白木の見えがかり部分を、洗浄力の高い「灰汁湯」で残ら ず洗うという仕様が明記される。

そして天保七年（1836）の知恩院集會堂では、さらに詳細な洗い の種別の存在が明らかになる。「内迴り拭ふき外廻り両妻共灰汁湯 洗」から、屋内は「拭（ぬぐい）ふき」屋外は「灰汁湯洗」と、場 所による仕様の使い分けがされていた。さらに「拭ふき」と「灰汁 湯洗」の中間の仕様と推察される「拭洗」が広縁周りの柱・長押 • 天井など、比較的経年による污れが少なかったと予想される個所に 行われていた。さらに「灰汁湯洗」は基本坪単価を四多とし、洗い 専用の足場の有無または目に触れる距離の違いなどの理由からか、 屋根周りは二分減の三多八分、「拭洗」はほぼ半值の二多七厘、「拭 ふき」はかなり值が下がって㚃分四厘で計上されていた。これらは、 同史料の壁方の壁補修費が、仕椂により坪単価四斥八分六厘から二 分四厘で計上されていることにより、左官と同等の坪単価が定めら れていたことも分かるのである。

以上に見られた洗いの種別（史料上の呼称）と、薬液・所作の関 係を Table2 にまとめた。「拭ふき」「拭」の場合、乾拭きか水拭き が基本で、灰汁などの薬液は使われていないと想定される。「拭洗」 は、呼称に含まれる「洗」の文字から、水洗いを行った後に拭き取 りを行い、灰汁は用いられなかったと想定される。「洗」は洗い行為 全般を示す基本的表現として史料中で最も多く見られ、大徳寺真珠 庵のように原料の葈が記されるなど、明記されていなくても灰汁を 用いた洗いが行われていた可能性が想定される。また薬液は明記さ れていないが、寬文期の延暦寺では切葍を用いた擦り洗いが見られ た。「灰汁洗」は、「灰汁を以て」「灰汁を致し」など薬液を明記して いる史料をTable 2 に事例として示した。「灰汁洗」は「洗」に含ま れる行為であるため、記録と呼称から、拭う・洗う（濯ぐ）擦る、 の所作は「洗」同様、各々想定される。「灰汁湯洗」は、灰を湯に溶 か寸か、灰汁を沸か寸等した薬液を用いた洗いである。高い洗浄効 果が想定されており、かつ湯によって木肌が軟化するため、擦りは 行われないか、優しく慎重に行う必要があったかもしれない。
一方「削る」所作については、引用史料上では、延暦寺の寛文修 理で洗いとの併用が見られたが、あくまで異なる部位での大工仕事 として行われている。同様の併用であれば全ての洗い行為で併用は 可能であるため、記録にないが想定される所作として table 2 に記入 した ${ }^{44)}$ 。

また、天保年間の知恩院を主として、全ての洗い行為は専用足場が 組まれた記録が存在する。左官や大工仕事と足場が併用できないよ うな、屋内外の細かな部位にて、拭う、洗う（濯ぐ）、擦る等といっ た繊細な所作を行い、薬液と道具の運搬が求められた結果と考えら れる。

\section{6. 近世文書にみる「洗い」の変遷}

ここまで、近世の作事関係文書における「洗い」の記録が残され た作事関係文書の記述から、用いられた用途物、施工者、洗いの種 別と所作について見てきた。以上をふまえ、近世における洗いの変 遷を考察する。

近世の洗いは、慶長から承応年間までの確立期、寛文から元禄年 間における発展期、天明から天保年間頃の成熟期に大別できる。

\section{確立期（慶長～承応年間頃）}

確立期である近世初期の作事文書では、灰汁の原料となる菜と洗 い手間のみが記載され、洗いは左官職人が壁塗りと共に行っていた。 しかしこの時期に、建物増築工事における古建築の洗い［大徳寺真 珠庵客殿・龍光院客殿］移築工事における古建築の洗い［南禅寺日 ノ門］修理工事における古建築の洗い［南禅寺祠堂］そして新築工 事における仕上げ拭き（新築の洗い）［大徳寺龍光院昭堂］という、 現代の洗い仕事でも見られるような諸条件での洗いが既に行われて いた。

\section{発展期（寛文〜元禄年間頃）}

発展期とした寛文から元禄年間の記録は、全史料のうち 6 点（内 5 点が元禄、 4 点が法隆寺関係文書) を占めており、記載内容も充 実してくる。工事ごとに洗いの仕様がある程度明記され、この時期 以降洗いの薬液として「灰汁」という言葉が用いられるようになる。 原料である萫麦营や垕麦がらが明示されるのは初期の 2 件 [福王寺

Table2 The relationship between the name of Arai and Washing liquid and Behavior seen in around Edo period documents 近世文書に見られる洗いの種別（呼称）と薬液と所作・設えの関係

\begin{tabular}{|c|c|c|c|c|c|c|}
\hline \multicolumn{2}{|c|}{$\begin{array}{c}\text { 洗いの種別（呼称） } \\
\text { Name of Arai }\end{array}$} & $\begin{array}{l}\text { 拭ふき・拭 } \\
\text { Nugui-buki, Nugui }\end{array}$ & \begin{tabular}{|l} 
拭洗 \\
Nugui-Arai
\end{tabular} & \begin{tabular}{|l|} 
洗 \\
Arai \\
\end{tabular} & $\begin{array}{l}\text { 灰汁（を以て）洗 } \\
\text { Aku-Arai }\end{array}$ & \begin{tabular}{|l} 
灰汁湯洗 \\
Aku-yu-Arai
\end{tabular} \\
\hline \multicolumn{2}{|c|}{$\begin{array}{c}\text { 洗いに使用される溶液 } \\
\text { Washing liquid }\end{array}$} & $\begin{array}{l}\text { 不使用または水 } \\
\text { Water or no liquid }\end{array}$ & \begin{tabular}{|l|} 
水 \\
Water \\
\end{tabular} & \begin{tabular}{|l} 
水（または灰汁） \\
Water \\
\end{tabular} & \begin{tabular}{|l|} 
灰汁 \\
Lye \\
\end{tabular} & \begin{tabular}{|l|} 
灰汁湯 \\
Hot 1ye \\
\end{tabular} \\
\hline \multicolumn{2}{|c|}{$\begin{array}{c}\text { 主要な記録年代と対象建物 } \\
\text { Recorded year and } \\
\text { Building name }\end{array}$} & $\begin{array}{l}\text { 慶安二年（1649）大徳寺龍光院 } \\
\text { Daitoku-ji Korinin Temple } \\
\text { 天保七年 (1836) 知恩院 } \\
\text { Chion-in Temple } \\
\end{array}$ & $\begin{array}{l}\text { 天保七年 (1836) } \\
\text { 知恩院 } \\
\text { Chion-in Temple }\end{array}$ & \begin{tabular}{|l} 
寛文 8 年（1668）延暦寺 \\
Enryaku-ji Temple \\
天明四年（1784）大徳寺興臨院 \\
Daitoku-ji Korinin Temple \\
\end{tabular} & \begin{tabular}{|l|} 
元禄九年（1696） 法隆寺 \\
Horyu-ji Temple \\
元禄六年 (1693) 福王子神社 \\
Fukuouji Shrine \\
\end{tabular} & $\begin{array}{l}\text { 元禄十四年 (1701) 北野天満宮 } \\
\text { Kitano tenman-gu Shrine } \\
\text { 天保七年 (1836) 知恩院 } \\
\text { Chion-in Temple } \\
\end{array}$ \\
\hline \multirow{5}{*}{$\begin{array}{c}\text { 記録と呼 } \\
\text { 称から想 } \\
\text { 定される } \\
\text { 所作・設え } \\
\text { Expected } \\
\text { behavior } \\
\text { from } \\
\text { record and } \\
\text { name }\end{array}$} & \begin{tabular}{|l|} 
拭う \\
Wipe \\
\end{tabular} & () & () & $\triangle$ & 0 & 0 \\
\hline & \begin{tabular}{|l|} 
洗う（濯ぐ） \\
Wash \\
\end{tabular} & - & () & () & () & () \\
\hline & \begin{tabular}{|l|} 
擦る \\
Scrub \\
\end{tabular} & - & - & 0 & 0 & $\triangle$ \\
\hline & \begin{tabular}{|l|} 
削る \\
Scrape \\
\end{tabular} & $\triangle$ & $\triangle$ & 0 & $\triangle$ & $\triangle$ \\
\hline & \begin{tabular}{|l|} 
専用足場 \\
Scaffolding
\end{tabular} & 0 & 0 & 0 & 0 & 0 \\
\hline \multicolumn{7}{|c|}{ く、想定されない所作 Unrecorded, unexpected be } \\
\hline
\end{tabular}


神社拝殿・法隆寺大湯屋表門］のみである。寛文八年（1668）の延 暦寺諸堂では、木肌をこする切葍と所作が示され、元禄九年 (1696) の大湯屋表門では、原料・薬液・道具類 ・作業自体が最も具体的に 記される。しかし翌十年の法隆寺聖霊院・三経院では「洗方」「洗屋 方」として洗い工事が左官から独立し、洗い屋の名前が記される一 方、作業自体の詳細は記されない。以降、洗いは「洗屋」の持つ専 門的技術として認知され、細かな洗いの手法を作事文書に明示寸る 必要が無くなったためか、洗いの原料・道具類・作業自体は具体的 に示されなくなる。[法隆寺聖霊院・三経院・北野天満宮諸堂] そし て元禄末期には、境内諸堂の白木部分をすべて「灰汁湯」で洗うと いう、施工部位の広範囲化と湯を用いた洗いの定着がみられる。[北 野天満宮諸堂]

\section{成熟期（天明～天保年間頃）}

成熟期とした天明から天保年間頃では、京都でも「洗方」が独立 した職方として明記され、洗い専用の足場が計上される。[大徳寺興 臨院客殿・知恩院諸堂］特に知恩院では、これまでは「あくを以洗」 「あくヨ致（中略）洗」「灰汁湯二而悉洗」等と表現されていた洗い の手法が「灰汁湯洗」という名詞で表現されるに至る。さらに「灰 汁湯洗」「拭洗」「拭いふき」という 3 種の仕様が施工部位によって 使い分けられ、「灰汁湯洗」を二段階に分けた四段階の坪単価も明記 されていた。洗いが修理普請等で独立した職種として一般化すると ともに、その仕様が確立され、一定規模の修理工事に異なる種別の 洗いが坪単価と共に明示されるに至るのである。

\section{7. 終わりに}

以上、 2 章で見てきた近世の作事関連文書を元に、3 章では洗い に用いられた用途物、4 章で洗いの施工者 5 章では洗いの所作と種 別について述べ 6 章において近世の洗いの変遷の考察を試みた。

洗いの記録が比較的多く発見され、洗い屋の記録も確認できた近 世中期以降は、戦国動乱後の復興のため大規模な普請が行われた時 期を終え、修理や増改築等の小規模の普請が主体となった時代であ った。寛文八年 (1668) に発令された三間梁規制で大規模な寺社建 築の建設が抑制され ${ }^{45)}$ 、小規模普請による建設・修理技術も様々に 試行錯誤され発達したものと考えられる。

また発見史料に偏りがあった可能性も否めないが、元禄期の洗い の記録が多く見られたことも一つの傾向である。特に、法隆寺伽藍、 北野天満宮諸堂、福王子神社諸堂と、域内建物全般に及ぶ大規模な 工事と共に行われていた点も興味深い。元禄期は江戸初期の活発な 建設活動が終り、修理工事に重点が置かれるようになったとされる 時期に当たる。また京大工頭中井家が公費で運営される中井役所が 成立した時代でもある ${ }^{46)}$ 。小普請の修理記録の作成が中井家支配の 下、近畿地方で徹底され、修理普請記録が多く残された結果、元禄 期の文書が多く見られたという可能性も考えられる。また元禄期は 文化・経済が活発化した時代として知られているが、その華やかな 気運が小普請ながら建築修復工事にも反映し、洗いが塗装の塗替え と共に行われ、古建築を視覚的に一新する工事が行われたのかもし れない。また、このような時代背景の下、解体修理をせずとも薬液 の洗浄力で建築を新しく見せることができる洗いに対する需要が増 加し、法隆寺文書に見られる「洗い屋」の成立を促したのかもしれ ない。
最後に、本論における今後の課題について述べたい。文中でも述 べたが、本論で示すことのできた洗いに関する史料の数は多くはな い。今後さらなる史料収集を近畿以外の地域等においても進め、研 究の深化を目指したい。また、本論では直接触れることができなか ったが、これらの史料分析を通した日本人の持つ建築の経年に対す る美意識についても、今後さらに研究を深めていきたい。

\section{謝辞}

本論を書くに当たって、様々にご助言下さいました先生方や、聞き 取りをさせて頂いた洗い職人の皆様に、この場を借りて心より感謝 申し上げます。なお、この研究成果の一部は JSPS 科研費 JP18K13910の助成を受けたものです。

\section{参考文献}

1) Rie Nakayama : Historical transition of "Arai" in Japanese wooden architecture: aesthetics of an ancient architecture considered from the purification techniques of cortex, Journal of Architecture and Planning (Transactions of AIJ), Vol. 76, No. 668, pp. 1951-1957, 2011. 10 (in Japanese)

中山利恵 : 日本の木造建築における「洗い」の歴史的変遷一木肌浄化処理 技術から見る古建築のありかたと美意識，日本建築学会計画系論文集，第 76 巻,第 668 号, pp.1951-1957, 2011. 10

2) Rie Nakayama : The characteristic and origin of the techniques of "ARAI" from the viewpoint of tools :A study of the tools of "ARAI" in Japanese wooden architecture, Journal of Architecture and Planning (Transactions of AIJ), Vol. 77, No.678,pp. 1939-1946, 2012.8 (in Japanese)

中山利恵 : 道具からみた「洗い」技術の特性とその起源一日本の木造建築 における「洗い」の道具に関する研究，日本建築学会計画系論文集，第 77 巻 678 号, pp. 1939-1946, 2012.8

3) Rie Nakayama : About the meanings of "SHIRA-KEZURI", "UWAKEZURI", and "SHIR s AKE" in EDO period documents, Journal of Architecture and Planning (Transactions of AIJ), Vol. 85, No.769,pp. 689-697, 2020. 3 (in Japanese) 中山利恵 : 近世文書にみる「白削」「上削」「しらけ」の意味について, 日 本建築学会計画系論文集，第 85 巻，第 769 号，pp. 689-697，2020.3

\section{注}

注1） 参考文献 2)

注2）参考文献 1)

注3）同上書

注4）同上書

注5）なお、大阪府内で発行されている指定文化財建造物の修理工事報告書に ついては、京都工芸繊維大学所蔵の約 40 冊を調査したが、掲載史料に近世 以前の洗いの記録は見られなかった。

注6）現在筆者が把握している範囲では、奈良県: 約 170 冊、京都府: 約 160

冊、滋賀 : 約 90 冊である。

注7）宗教法人龍光院 : 国宝竜光院書院ほか二棟並びに京都府指定有形文化 財(建造物)龍光院寮及び小庫裏修理工事報告書, $2015, \mathrm{pp} .62-83$ 掲載史料

(以後文書の引用に際しては、旧字や変体がなは原則として常用漢字に改 め、建築用語として影国社『建築大辞典』に用例のある漢字等はそのまま 用いる事とした。

注8）なお、伊勢神宮における遷宮記には、完成した社殿の殿内を洗い清め る「洗清」という竣工儀式があることを確認している。（神宮司庁編『神宮 遷宮記』)

注9）国宝延暦寺根本中堂修理事務所 : 重要文化財延暦寺大講堂修理工事報

告書, 1955 , p.14

注10） 同上書 pp.35-43 掲載史料

注11）「しらけ」の意味については、参考文献 2)に詳しい。

注12) 前掲書 注 9 p.42

注13）「法楽」は読経・奏楽などによって神仏を楽しませること、また神仏 
に和歌や芸能などを奉納することを意味する。(『日本国語大辞典』) 落慶法 要における事例としては、古くは天平勝宝四年（752）の東大寺大仏開眼供 盖会や、治安二年（1022）法成寺金堂落慶時における舞楽奉納が知られ ている。(小野 功竜 : 供養舞楽と法会形式の変遷に就いて, 相愛女子大学・ 相愛女子短期大学研究論集,第 12 巻,第 13 号,1966,pp.131-144)

注14）浪花言葉を江戸言葉を以て註した文政 2 年（1819）頃の『浪花聞書』 には「きりわら 江戸のたわし也」との記載がある。（安原貞室 : 片言 付補 遺 物類稱呼 浪花聞書 丹波通辞, 日本古典全集刊行会, 1931, p.22）また、 『日本国語大辞典』には、「わらを束ねて、一○センチメートルぐらいに短 く切って作ったたわし」とある。

注15）きつねごうし［狐格子］宮殿・社寺・城郭などにおける妻飾の一。入 母屋造り妻をふさぐ格子。「妻格子」とも言う。(建築大辞典 第 2 版, 彰国 社, 1993)

注16）京都府教育委員会: 重要文化財福王子神社拝殿及び本殿修理工事報告 書, 2001, pp.52-62 掲載史料

注17）同上書 p.52

注18）奈良県文化財保存事務所 : 重要文化財法隆寺大湯屋 - 大湯屋表門・西 南隅子院築垣修理工事報告書, 1974, pp.85-88 掲載史料

注19）法隆寺国宝保存事部：国宝法隆寺聖霊院修理工事報告, 1955 ,pp. $146-147$ 掲載史料

注20）『元禄四年 年会所記録』に、「聖霊院修復入札有之古摩堂モ一所也浦 町大工安兵衛壱貫二百三多五分二落札」とあるため、同年護摩堂と共に修 復入札を落札した浦町大工への支払いと考えられる。（前掲書 注 19 p.147） 注21）前掲書 注 19, pp.161-162 掲載史料

注22）井筒屋 七郎兵衛江は、貞享四年 (1687) 比踥山の西塔修復を一式落 札した「井筒屋 辻七郎兵衛江勝蔵」と同一人物と思わる。谷直樹は、「井 筒屋 辻七郎兵衛江勝蔵」を、当時京都で両替商を営んでいた「井筒屋七郎 兵衛江」と比定し、当時の入札工事には資本力の豊かな商人が一式入札す る傾向が強かった事を指摘している。(谷直樹 : 幕府御用作事における中井 家の職務と財政構造 川上貢編 : 近世建築の生産組織と技術,中央公論美術 出版, 1984, pp.33-34)

注23）前掲書 注 19, pp.162-163 掲載史料 なお、本書では洗い屋の名前は 「八左衛門」と翻刻されていたが、聖徳宗総本山 法隆寺様に史料をご確認 頂き、『修理方惣勘定帳』『諸伽藍普請金銀緒拂帳』共に「八右衛門」であ ると判断した。

注24）同上書 注 $19, \mathrm{p} \cdot 18-20$

注25）北野天満宮史料刊行会編：北野天満宮史料 遷宮記録三，北野天満宮， 2003, pp.192-194

注26）現代の洗い職人もかつて洗いに湯を使っていたという証言を多数得て いる。これは、灰汁を煮出す、または固形の苛性ソーダを溶かす目的で用 いられた他、湯を用いることでより高い洗浄効果があったという職人もい た。

注27）前掲書 注 26, pp.192-236

注28）京都府教育庁指導部文化財保護課編: 重要文化財興臨院本堂附玄関及 び表門修理工事報告書, 1978 , pp.44-45 掲載史料

注29）京都府教育庁指導部文化財保護課編：国宝・重要文化財知恩院本堂及 び集會堂ほか二棟修理工事報告書, 2012, pp.129-138 掲載史料

注30）同上書 なお、同書は史料掲載に当たり影印と翻刻を併記する方法を 取っている。ここでの「拭洗」は同書では「掛洗」と翻刻されていたが、 影印との比較、前半の仕様説明文中では同じ文字が「内廻り拭ふき」と翻 刻されている点（同書 $\mathrm{p} 129 ） 、$ 筆者のこれまでの研究を踏まえ、「拭洗」で あると判断した。

注31）ここでの「拭ふき」も同書では「掛ふき」と翻刻されていたが、上述 した理由により「拭ふき」であると判断した。

注32）前掲書注 30 p.136

注33）木道具は、建築に使う材木、用材の意。(『日本国語大辞典』小学館,2006) 注34）ここでの「口ばら木」は前掲書注 30 では「いばら木」と翻刻されて いたが、影印では欠損していたため「ロばら木」としている。

注35） 前掲書注 30 p.138

注36) 同上書 p.58

注37）笠井八重子,山際 あゆみ,大野婦美子 : 芋こんにやくの伝統的製造法 における凝固財「灰汁」利用の特徴—「炭酸ナトリウム」のゲル化特性 の「灰汁」との類似性, 岡山大学教育学部研究集録 134,2007, p.110 表 2 によれば、ソバ灰汁は ph13.6 13.0 であるのに対し、イネワラ灰汁は ph9.9
が示されている。なお、現在までの筆者による現代の洗い職人への聞き取 りでは、灰汁に用いられていたのは専ら稲荣であった。

注38）参考文献 2)

注39）参考文献 2) p1943

注40）前掲書 注 19p.163 なお、ここでの左官も「八右衛門」である点は興 味深い。「南都洗い屋八右衛門」と同一人物が、左官と仕事を兼務しながら、 別途工事として洗いを引き受けていた可能性も少なからず考えられる。

注41）今回調査不足のため本論での言及を避けたが、東京都立図書館蔵『塗 師方壁方瓦方当時物本途内訳』文化元年 (1804) には、塗師方の項目に「灰 汁洗い」の記載がある。元文化財建造物保存技術協会技師の今井成享氏に ご教示頂いた。また、新材の木材表面の養生のため「砥の粉摺り」と呼ば れる技術がある。『建築大辞典 第二版』(影国社,1993) によれば「砥の粉 を水に溶いて、鉋仕上げした木材の表面に塗ること。鉋仕上げした木材表 面の污れを防止する目的で行う。(中略) 砥の粉は水に溶いて布に染みこま せ拭うように塗る」とある。主に大工やその手伝い等が行っていた作業で あるが、塗師による漆や塗装の素地調整の技術が伝えられた可能性がある。 最近は殆どが紙張り養生になったためあまり見られないが、養生用の砥の 粉を洗い流寸仕事をしたことがあるという洗い職人がいた。同氏によれば、 砥の粉は 3 年もすると土焼けで真つ黒になるから、それを酸で洗う必要が あるという。(洗い屋 玉田勝慶氏 2010 年 6 月 7 日聞き取り調査)このこ とから、砥の粉䅛りは木材の養生として一定の有効性があり採用されてい たと想定されるが、特に白木に用いた場合の有効性や、技術がいつまで遡 るのか等については、今後さらなる調查が必要である。

注42）武谷 嘉之：近世大坂における家作「手伝」職の仲間形成，社会経済 史学, 65,pp. 45-65,1999 によれば、近世の『大阪市史』等で確認できる他 職の手伝いに対する禁令の多さから、「手伝」の他職人への進出が盛んであ ったことが指摘されている。

注43）洗い職人への聞き取りから、農閑期の百姓が洗いを始めたという言い 伝えが得られている。(参考文献 2 参照。)

注44）なお、現代に残る伝統的な洗いには、施工前に木肌を削る「コソゲ」 という道具が存在し、技術上ではすべての洗いと削りを同一部位で施工す ることも現代では想定されるが、洗い屋による削りがいつまで遡れるのか については、さらなる検証が必要である。(参考文献 2 参照。)

注45）水野耕嗣：梁間規制について 近世都市・建築法制史の研究 3 , 日本 建築学会学術講演梗概集，計画系 $51,1976, p .1709$ 、光井涉 : 社寺建築への 法的規制, 近世寺社境内とその建築, 中央公論美術出版,2001, pp.123-126 初出 : 建築史学, 第 22 号, 1994 等。

注46）島田 武彦: 京都大工頭中井支配の棟梁について(1) (5), 日本建築学 会近畿支部研究報告集, 1953 1955、谷直樹 : 幕府御用作事における中井家 の職務と財政構造, 川上貢編 : 近世建築の生産組織と技術,中央公論美術出 版, 1984 


\title{
ABOUT THE “ARAI” , AND “ARAI-YA” IN DOCUMENTS FROM AROUND THE EDO PERIOD
}

\author{
Rie NAKAYAMA*1 \\ ${ }^{1}$ Assoc. Prof., Dept. of Architecture and Design, Kyoto Institute of Technology, Dr.Eng.
}

This paper analyzes the depiction of "ARAI" work-related documents from around the Edo period to clarify the objects used for "ARAI," the operators who performed the ARAI, and the respective activities involved in ARAI jobs.

In this paper, in addition to the three historical documents described in the previous paper, 10 new documents relating to ARAI from around the Edo period were discovered. In Chapter 2, the contents of the description of ARAI in these 10 historical documents are exhibited in chronological order. In Chapter 3, based on the results of Chapter 2, the objects applied for ARAI are exhibited. Lye is used as a cleaning solution for the ARAI of wooden surfaces, and "Hot lye" has been used since the early 18th century. Also, "Buckwheat straw," which is more alkaline than rice straw, can be used as raw materials for lye. Further, it turns out that Sasara brush and scourer made of rice straw were used as tools to physically rub wooden surfaces. Similar tools are used in current era traditional ARAI. Chapter 4 described the ARAI operators. Until the mid 17th century, plasterers were performing the ARAI. However, it was revealed that at the end of the 17th century, a specialized craftsman named " Nanto Arai-ya Hachiuemon" existed during the repair of the Horyuji Temple. Thereafter, it was exhibited that the ARAI was carried out by professional craftsmen described as "Arai-ya" and "Arai-kata". In Chapter 5, the activity and types of ARAI are described.

In Chapter 6, the transition of ARAI in around the Edo period is considered. For ARAI during the establishment period from Keicho to the Joo era (early to middle of the 17th century), only the straw, which is the raw material of the lye, and time and labor required for ARAI is depicted., and ARAI was conducted along with wall paintings by the plasterer.

ARAI during the development period of the Kansei era to the Genroku era (late 17th century to early 18th century) accounted for approximately half of the historical documents at six items ( five items in the Genroku era and four items from the Horyu-ji Temple document). The most specific descriptions of raw materials, chemicals, tools, and activities were written on the front gate of Horyu-ji Temple Oyuya in 1696. Also, "Arai-ya" and "Arai-kata," who are specialists in ARAI, first appeared in the recorded documents. During the maturity period from the Tenmei to the Tenpo eras (late 18th century to early 19th century), scaffoldings dedicated to ARAI were built. In addition, at Chion-in Temple in 1836, three types of specifications, "Arai with hot lye," "Arai by wiping," and "Wiping," were used according to the operating site, and a four-step operating unit price was specified. In the maturity period, it is considered that ARAI became generalized as an independent occupation, its specifications were established, and different ARAI types were explicitly displayed along with the unit price per lot for repair work of specific sizes.

(2020 年 9 月 10 日原稿受理, 2021 年 2 月 18 日採用決定) 